\title{
Petrografia, geocronologia e significado tectônico do Nefelina Sienito Brejinho: extremo noroeste da Província Borborema
}

\author{
Paulo Sergio de Sousa Gorayeb ${ }^{1}$, Rita de Cássia de Oliveira Barbosa ${ }^{1}$, Candido Augusto \\ Veloso Moura ${ }^{1} \&$ Ronaldo Lima Lemos ${ }^{1}$
}

\begin{abstract}
Resumo No extremo noroeste da Província Borborema foi identificado um maciço alcalino subsaturado, o Nefelina Sienito Brejinho (NSB), alojado em gnaisses do Paleoproterozoico do Complexo Granja. As investigações envolveram mapeamento de detalhe do corpo, acompanhado de análises petrográficas e geocronológicas, que permitiram reconstruir a sua história evolutiva. Foram identificadas cinco fácies petrográficas, com a sua distribuição cartográfica, associações mineralógicas presentes e análises texturais/estruturais sugerindo a atuação de processos de cristalização fracionada, com forte controle da ação da gravidade e imiscibilidade de líquidos na história da cristalização magmática do maciço. Os estudos geocronológicos realizados pelo método $\mathrm{Rb}-\mathrm{Sr}$ em rocha total revelaram valor de $554 \pm 11 \mathrm{Ma}$, interpretado como a idade mínima para cristalização e emplacement do NSB, no final do Neoproterozoico. No contexto tectônico, esse magmatismo alcalino pode ser relacionado ao evento extensional responsável pela implantação do Gráben Jaibaras e seus correlatos no oeste do Ceará, assim como à granitogênese da região, cujas idades situam-se no intervalo entre 530 e 590 Ma. Situação semelhante é reconhecida na borda norte da Bacia do Amazonas, com o Complexo Alcalino-Ultramáfico-Carbonatítico Maicuru (589 Ma) alojado no embasamento gnáissico paleoproterozoico do Cráton Amazônico. A situação geológica e temporal do NSB permite situá-lo posteriormente à tectônica transcorrente representada na área pela Zona de Cisalhamento Santa Rosa, uma ramificação do Lineamento Transbrasiliano, e anterior à Bacia do Parnaíba. Disso resulta que esse magmatismo alcalino pode ser interpretado como um importante registro da fase rifte que prenunciou a instalação dessa bacia no início do Paleozoico. A sua caracterização, até então sem similar na Província Borborema, abre novas perspectivas de pesquisa em todo o embasamento da Bacia do Parnaíba, tendo em vista a importância tectônica e metalogenética desse tipo de magmatismo.
\end{abstract}

Palavras-chave: Nefelina Sienito Brejinho, magmatismo alcalino, geocronologia Rb-Sr, Província Borborema.

\begin{abstract}
Petrography, geochronology and tectonic significance of Brejinho Nepheline Syenite: NW Borborema Province. In the extreme northwest of the Borborema Province was identified an alkaline massif named Brejinho Nepheline Syenite, emplaced in Paleoproterozoic gneisses of the Granja Complex. The investigation involved the mapping, detailed petrographic analyses and $\mathrm{Rb}$-Sr geochronology, allowing to the reconstruction of the evolutionary history of this pluton in the tectonic context of the Borborema Province. Five petrographic facies have been mapped and the mineralogical and textural/structural analyses performance suggest the processes of fractional crystallization, with strong control of gravitational action and liquid immiscibility in the history of magmatic crystallization of the massif. The age of $554 \pm 11$ Ma was obtained by Rb-Sr wholerock geochronology and was interpreted as the minimum age for crystallization and emplacement of Brejinho Nepheline Syenite in the late Neoproterozoic. The tectonic context of the alkaline magmatism may be related to the extensional event responsible for the formation of Jaibaras Graben in western Ceará, as well as the emplacement of a number of granitic plutons whose ages range from 530 to $590 \mathrm{Ma}$. Similar situation was identified in the north of the Paleozoic Amazon Basin involved the Maicuru Alkaline-Ultramafic-Carbonatite Complex (589 Ma) emplaced in the Paleoproterozoic gneissic basement of the Amazoniam Craton. The geological framework places the Brejinho Nepheline Syenite after the strike-slip tectonics represented by Santa Rosa Shear Zone (Transbrasiliano Lineament), and before the formation of the Parnaíba Basin. Therefore, this alkaline magmatism may be interpreted as an important record of the rift phase that heralded the installation of the basin in the early Paleozoic. The identification of this alkaline massif, so far without any similar occurrence in the Borborema Province, opens new perspectives for research in basement of Parnaiba Basin, considering the tectonic and metallogenic importance that represents this type of magmatism.
\end{abstract}

Keywords: Brejinho Nepheline Syenite, plutonic alkaline magmatism, Rb-Sr geochronology, Borborema Province.

1 - Programa de Pós-Graduação em Geologia e Geoquímica, Instituto de Geociências, Universidade Federal do Pará, Belém (PA), Brasil.E-mail: gorayebp@ufpa.br, rickassy@hotmail.com,candido@ufpa.br,rlemos@ufpa.br 
INTRODUÇÃO Rochas alcalinas stricto sensu são relativamente raras, embora amplamente distribuídas em todos os continentes, e representam menos de $1 \%$ das rochas magmáticas da Terra. No caso de rochas alcalinas subsaturadas, como os complexos de nefelina sienitos, elas são mais restritas ainda. Na literatura mundial está registrada uma gama de províncias magmáticas em vários continentes e em diferentes ambientes geotectônicos e períodos geológicos (Sorensen 1974, Ulbrich \& Gomes 1981, Platt \& Mitchell 1982, Woolley 1987, Morbidelli et al. 1995, Platt 1996, Comin-Chiaramonti \& Gomes 2005).

No território brasileiro são destacadas as províncias alcalinas e alcalina-carbonatíticas do Mesozoico ao Cenozoico (Ulbrich \& Gomes 1981, Morbidelli et al.. 1995, Comin-Chiaramonti \& Gomes 2005) e a província alcalina neoproterozoica do sul da Bahia (Rosa et al. 2007). Em outras regiões (p.ex. a Amazônica), as ocorrências de rochas alcalinas são isoladas, e não há conhecimento suficiente para a definição de províncias.

No caso da Província Borborema, rochas alcalinas raramente têm sido descritas e os exemplos conhecidos compreendem plútons graníticos com tendência alcalina com idades entre 587 a $532 \mathrm{Ma}$, como as intrusões graníticas de Meruoca, Mucambo, Serra da Barriga, Pajé e Anil (Costa et al. 1979, Sial 1987, Gorayeb et al. 1988, 1991, 1993, Tavares Jr. et al. 1991, Lafon et al. 1992, Gorayeb \& Lafon 1995, Arcanjo et al. 2009), e granitos alcalinos sódicos, como os de Morrinhos e São Paulo (Gorayeb \& Monteiro 1996). Entretanto, tipos subsaturados não são conhecidos na Província Borborema, à exceção das ocorrências do sul da Bahia.

Granitos alcalinos sódicos, como os dois últimos maciços, constituem pequenos corpos de albita granitos intrusivos em gnaisses do Complexo Tamboril-Santa Quitéria (Gorayeb \& Monteiro 1996). Na Bacia de Jaibaras, sucessões de basaltos com tendência alcalina, associados com riolitos e traquitos reunidos na Suíte Parapui (Nascimento \& Gorayeb 2004), foram relacionados à tectônica extensional do final do Neoproterozoico/início do Paleozoico (Abreu et al. 1993, Gorayeb et al. 1993).

As sucessões vulcânicas e subvulcânicas de tefritos, fonólitos, traquitos, tufos alcalinos e essexitos, incluídas na Suíte Magmática Messejana (CPRM 2003) são bem mais novas, do Terciário.

$\mathrm{O}$ primeiro plúton de nefelina sienito relatado na literatura no noroeste da Província Borborema foi descrito por Gorayeb \& Abreu (1997), no nordeste do estado do Piauí, que o denominaram Nefelina Sienito Brejinho, posicionando-o no Proterozoico, e que é objeto do presente estudo. Este trabalho apresenta os resultados do mapeamento de semidetalhe da região de Brejinho do Pé da Serra localizada a $60 \mathrm{~km}$ a sudeste da cidade de Parnaíba (Piauí), próxima à fronteira com o estado do Ceará, onde está localizado o plúton. Ele inclui cartografia geral da área e interna do plúton, análise petrográfica de detalhe das rochas alcalinas e encaixantes, petrologia, e geocronologia pelo método $\mathrm{Rb}-\mathrm{Sr}$ em rocha total. $\mathrm{O}$ artigo também discute o significado tectônico e a importância desse magmatismo, e a sua contextualização na geologia do noroeste da Província Borborema.

O CONTEXTO GEOLÓGICO REGIONAL Aárea está situada no extremo noroeste da Província Borborema (Almeida et al. 1977) no domínio geotectônico denominado Cinturão Noroeste do Ceará (Abreu et al. 1988). Os mapas das figuras 1 e 2 mostram a distribuição e a organização das principais unidades da região estudada. A unidade mais antiga está representada pelo Complexo Granja de idade entre 2,35-2,10 Ga, do Paleoproterozoico (Gaudette et al. 1993, Fetter et al. 2000), que é constituído dominantemente por ortognaisses tonalíticos mais ou menos migmatizados, associados com granada-biotita gnaisses, biotita xistos, quartzitos e anfibolitos.

O Granito Chaval, intrusivo nos gnaisses desse complexo, destaca-se no relevo em rochedos expostos, como na Serra do Chumbo. É formado por rochas porfiríticas, com fenocristais euédricos de microclina centi a decimétricos, envolvidos em matriz de granulação grossa reunindo quartzo, microclina, plagioclásio e biotita. De um modo geral, as rochas exibem marcantes feições miloníticas (textura porfiroclástica) com estruturas tipo augen e foliação S-C com quartzo fitado, anastomosado. Datações $\mathrm{Pb}-\mathrm{Pb}$ em zircão indicam para essas rochas a idade de 1,99 Ga (Gorayeb et al. 1995). Contudo, o valor de $0,59 \mathrm{Ga}$ foi obtido por Fetter (1999) em monazita magmática, o que apontaria para a sua formação no Neoproterozoico, sendo que as idades mais antigas poderiam corresponder a zircões herdados. Outra unidade litoestratigráfica reconhecida é o Grupo Martinópole, representando uma sequência supracrustal do Neoproterozoico.

A área é fortemente estruturada, em razão de estar situada no Cinturão Noroeste do Ceará, ao longo da Zona de Cisalhamento Santa Rosa, que representa um sistema transcorrente dextral de alto ângulo, semelhante a outros lineamentos da região (Sobral-Pedro II, Jaguarapi, Adrianópolis, Granja, Forquilha etc.) e afeta tanto os gnaisses quanto os granitoides. As estruturas, como foliação milonítica e bandamento tectônico, possuem orientações preferenciais na direção NNE-SSW com altos ângulos de mergulho e lineação de estiramento, seguindo a mesma direção com mergulhos subhorizontais para os quadrantes NE e SW. O plúton alcalino Brejinho é intrusivo nos gnaisses do Complexo Granja e trunca toda essa estruturação (Fig. 2).

$\mathrm{Na}$ parte SW da área, as expressivas camadas sub-horizontais de arenitos do Grupo Serra Grande (Bacia do Parnaíba) sustentam a terminação norte da Serra da Ibiapaba e se acham assentadas, em franca discordância erosiva, sobre os gnaisses e granitoides descritos acima. Há também mesetas isoladas em morros testemunhos, com destaque para a Serra de Santa Rita, que cobre parcialmente a porção centro-sul do plúton Brejinho. Nas porções N e NW, as unidades mais antigas são cobertas por depósitos sedimentares da costa Atlântica (Fig. 2). 


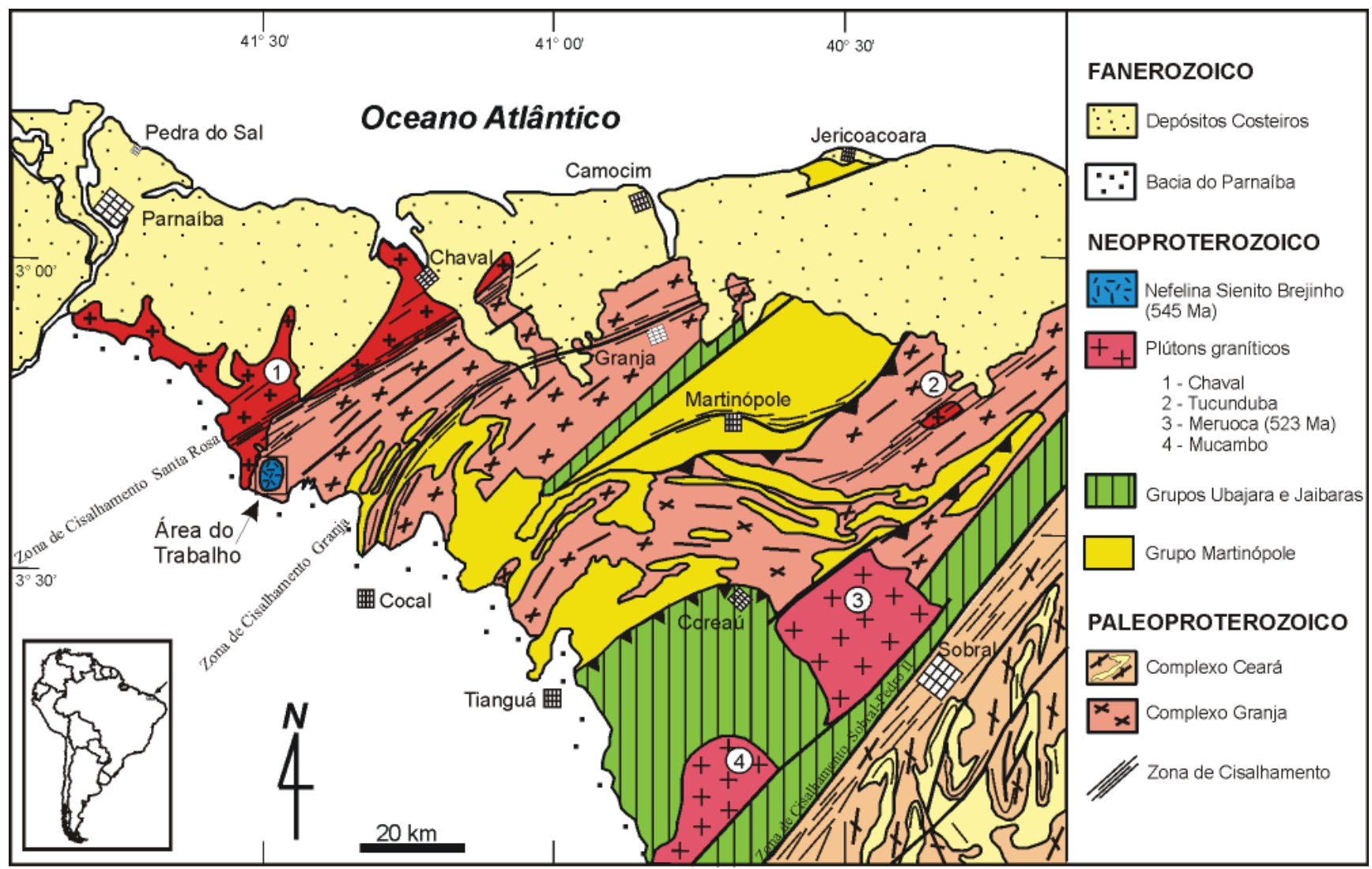

Figura 1 - Mapa geológico do noroeste da Província Borborema com a localização da área de trabalho. Elaborado a partir de Costa et al. (1979), Abreu et al. (1988), CPRM (2003) e DNPM (1985).

\section{O PLÚTON NEFELINA SIENITO BREJINHO}

(NSB) Este plúton foi descrito originalmente por Gorayeb \& Abreu (1997) que, utilizando-se de cartografia geológica de semidetalhe juntamente com dados estruturais, relações de campo e estudos petrográficos, o posicionaram estratigraficamente num amplo intervalo de tempo entre o Paleoproterozoico e o Neoproterozoico, sugerindo uma vinculação com episódios de tectônica extensional do Neoproterozoico. O mapa da figura 2 mostra a geologia do corpo e as relações com as demais unidades da área.

O plúton é intrusivo em gnaisses do Complexo Granja e possui forma aproximadamente subcircular com cerca de $16 \mathrm{~km}$ comprimento na direção N-S por $8 \mathrm{~km}$ de largura. Entretanto, a sua real dimensão não foi definida devido encontrar-se coberto por depósitos cenozoicos em suas bordas norte e noroeste.

O corpo destaca-se no relevo na sua porção centro-sul (Serra de Santa Rita), que atinge altitude de aproximadamente $400 \mathrm{~m}$, onde está parcialmente coberto por uma camada de arenitos sub-horizontais do Grupo Serra Grande, definindo uma meseta em morro testemunho. Nas demais partes, o relevo se mostra rebaixado, com pequenos morros, colinas ou pedrais desmoronados.

Relações de contato tipicamente intrusivas foram observadas nos flancos sul e leste do corpo alcalino. As foliações dos gnaisses encaixantes estão truncadas ou deformadas nas proximidades da região de contato, tendendo a acompanhar as bordas do corpo em razão do alojamento intrusivo forçado do plúton. Margens de resfriamento, presença de xenólitos de gnaisses parcialmente assimilados na borda interna do corpo e zonas métricas de hornfels indicam condições relativamente rasas para o alojamento do plúton. Nas zonas de hornfels mais próximas do contato reconhecem-se neoblastos de granada e biotita dispostos aleatoriamente (textura decussade, Spry 1969) e indícios de fusão parcial nos gnaisses encaixantes (Fig. 3A). A paragênese metamórfica granada+biotita+álcali-feldspato+plagioclásio, aliada à ocorrência de porções anatéticas, indicam condições da fácies hornblenda hornfels, a baixas pressões ( $\leq 3 \mathrm{kbar}$ ) e temperaturas mínimas de $650^{\circ} \mathrm{C}$ para o processo metamórfico de contato.

De um modo geral, o NSB é um corpo plutônico, tipicamente ígneo, de natureza alcalina subsaturada, constituído principalmente por rochas leucocráticas a mesocráticas de cor cinza ou marrom (esta devida à presença de nefelina), granulação grossa com variações mais finas em alguns setores das suas margens externas (bordas de resfriamento) e nos limites entre algumas fácies petrográficas. Os principais tipos petrográficos são egirina-nefelina sienitos, biotita-nefelina sienitos, nefelina microssienitos, melassienitos, pegmatitos sieníticos e piroxenitos alcalinos. 

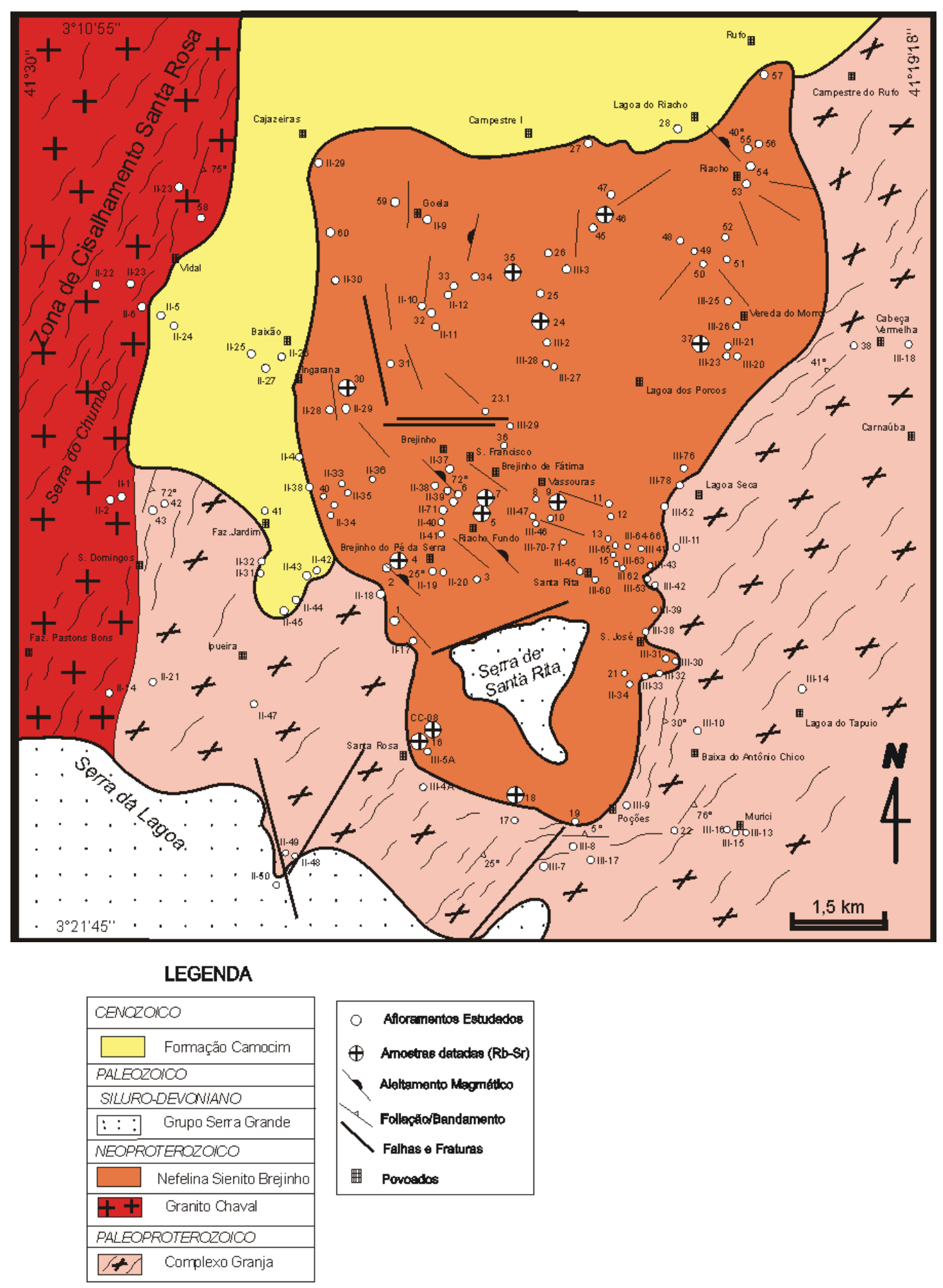

Figura 2 - Mapa geológico da área do estudo, com destaque para o plúton Brejinho e o posicionamento dos afloramentos estudados.

A estruturação interna é uma característica marcante por todo o plúton, uma vez que são frequentes as estruturas de fluxo magmático evidenciadas pela orientação preferencial de cristais euédricos, tabulares, de álcali-feldspato, piroxênio e anfibólio alcalino, que desenham uma foliação e acamadamento magmático nas rochas (Fig. 3B), com as suas atitudes plotadas no mapa da figura 2. Esta orientação é também ressaltada pelos minerais máficos com suas formas prismáticas e maior comprimento seguindo a mesma orientação preferencial, definindo microscopicamente típicas texturas traquitoides (Mackenzie et al. 1982). Essas texturas/estruturas tornam-se realçadas por um bandamento composicional rítmico. De natureza ígnea, este é caracterizado pela 
presença de lâminas concentradas de minerais félsicos alternados ritmicamente com minerais máficos (textura cumulada) na escala milimétrica e centimétrica, e que são indicativas da atuação de processos de acumulação gravitacional na geração dessas rochas, conforme demonstrado por Mitchell \& Platt (1982). Embora essas estruturas magmáticas sejam comuns por todo o plúton, há variações na sua orientação, predominando a direção NW-SE, com ângulos de mergulho baixos a médios para NE, nas porções centro-oeste e nordeste do corpo, e a direção N-S na parte norte (Fig. 2).
As outras estruturas presentes compreendem pequenas falhas e fraturas localizadas, que demonstram que o corpo não foi afetado por processos tectono-metamórficos regionais. Os dados estruturais, as relações de campo e os dados petrográficos evidenciam que o plúton Brejinho é cronologicamente mais novo que a Zona de Cisalhamento Santa Rosa.

Nas porções internas do corpo foram identificados, mais raramente, enclaves centimétricos de piroxenito alcalino que, em suas formas alongadas, se encontram alinhados acompanhando a estruturação magmática e,
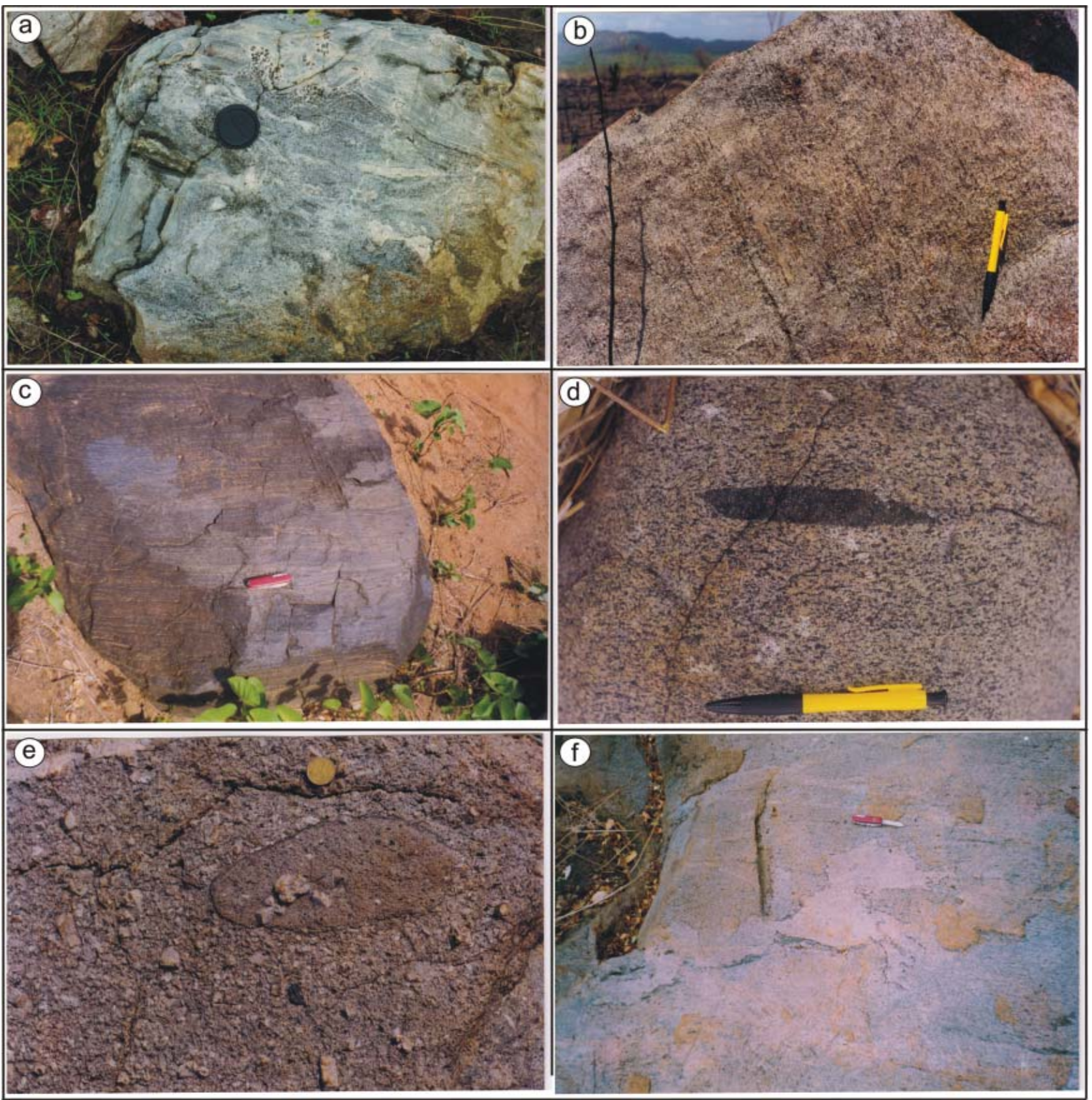

Figura 3 - Feições gerais do plúton Brejinho: A) hornfels em gnaisse encaixante com concentrados de granada e biotita, e porções anatéticas; B) marcante acamadamento magmático em nefelina sienito; C) camada de piroxenito alcalino com bandamento magmático rítmico; $D$ ) enclave de piroxenito alcalino envolvido em nefelina sienito; E) xenólito de microssienito com xenocristal envolvido em sienito porfirítico; F) porções irregulares de leucossienito das fases mais tardias injetado em sienito. 
provavelmente, representando frações de rochas ultramáficas alcalinas provenientes de níveis mais profundos do complexo (Fig. 3D).

Em outra situação são encontradas camadas métricas de melassienito ou piroxenito alcalino intercalados em nefelina sienito, com marcante laminação magmática e bandamento rítmico que representam níveis cumulativos indicando fracionamento magmático (Fig. 3C).

Outros tipos de enclaves são definidos por formas ovaladas, centimétricas, de microssienito com xenocristais envolvidos em sienito porfirítico (Fig. 3E). Essas feições podem ser interpretadas como relacionadas a processos de mistura de magmas entre as frações do magma alcalino, representadas pelas fácies petrográficas identificadas e descritas a seguir.

Outra feição diz respeito a porções irregulares de leucossienitos injetadas em sienitos representando fases mais tardias da evolução do plúton (Fig. 3E).

As considerações acima e as comparações com outros plútons, mesmo de idades diferentes, indicam que o NSB apresenta feições semelhantes a muitos exemplos clássicos de corpos dessa natureza, relatados na literatura.

\section{PETROGRAFIA E FACIOLOGIA DO PLÚTON} BREJINHO Usando os parâmetros de cores das rochas, índice de coloração, granulação e análise estrutu$\mathrm{ral} /$ textural, associação mineralógica e suas quantificações (análise modal), e relações de campo, foi elaborada a cartografia interna do plúton, a partir de estudos de semidetalhe efetuados em mais de uma centena de afloramentos (Figs. 2 e 4). Três fácies petrográficas principais foram identificadas: Clinopiroxênio-Microclina Sienito (CpxMS), Clinopiroxênio-Nefelina Sienito (CpxNS) e Leucossienito (LS); além de outras de menor expressão como Melassienito e Piroxenito (MM). Para este estudo, utilizou-se como base para classificação das rochas as propostas de Sarantsina \& Shinkarev (1967 apud Sorensen 1974), Streckeisen (1976), Mitchell (1996) e Le Maitre (2002).

No diagrama APF da IUGS (Streckeisen 1976, Le Maitre 2002), devido à absoluta ausência de plagioclásio, a maioria das rochas está projetada na linha F-A do diagrama caracterizando os tipos álcali-feldspato sienito e feldspatoide sienito (Fig. 5A). Em uma única amostra foi identificado quartzo em quantidade inferior a $10 \%$ modal, sendo então classificada como Quartzo-Microclina Sienito. No diagrama ANeM de Sarantsina \& Shinkarev (1967 apud Sorensen 1974), a distribuição é mais variada, porém, com a grande maioria das amostras situando-se também preferencialmente no campo dos sienitos com nefelina e nefelina sienitos, com variações aos extremos leucossienitos e malignitos (Fig. 5B). Os clinopiroxênio-microclina sienitos estão alinhados no lado AM, na base do diagrama, e ocupam os campos dos Sienitos Mesocráticos e Sienitos Melanocráticos com nefelina, projetando-se até o inicio do campo dos Álcali-Gabros.
Esse trend é determinado pela variação no conteúdo de máficos. Há também um outro trend definido pelos nefelina sienitos, que se dirige ao centro do diagrama em direção ao campo dos Malignitos, e é determinado pelo aumento do teor de nefelina. A seguir, serão descritas detalhadamente as fácies.

\section{Fácies Clinopiroxênio-Microclina Sienito (CpxMS)}

As rochas que caracterizam esta fácies foram identificadas em grande número de afloramentos e, em termos de distribuição cartográfica, a sua ocorrência é das mais amplas, ocupando as porções centro-sul, nordeste e noroeste do plúton (Fig. 4). No geral, as rochas exibem coloração marrom, granulação grossa com variações do índice de cor, de leucocrático a mesocrático $(\mathrm{M}=$ 15 a 40). Os aspectos texturais mais marcantes são a estrutura/textura traquitoide, em que os cristais tabulares de álcali-feldspato e os minerais máficos estão alinhados subparalelamente definindo um aleitamento ígneo (Figs. 3B, C e 6E). De modo mais restrito estão presentes leitos milimétricos com acumulações de clinopiroxênio e biotita.

O conteúdo mineralógico é dominantemente formado por microclina ( $\sim 52-89 \%)$ e egirina-augita (3 a $40 \%$ ) e, de modo subordinado, por anfibólio sódico, biotita e titanita. Os acessórios são titanita, apatita e minerais opacos.

Os cristais de microclina apresentam-se em formas tabulares, predominantemente euédricas, ou como cristais granulares subédricos com maclamento tipo Carlsbad e Xadrez. Cristais maiores mostram intercrescimento pertítico, com as lamelas dispostas ortogonalmente ao comprimento maior dos cristais. Nestes também ocorrem inclusões aciculares de egirina-augita e apatita, bem como lamelas de biotita. O plagioclásio, do tipo albita, aparece apenas em pequenos aglomerados nos limites dos cristais de microclina, como coroas representando fases dos intercrescimentos pertíticos.

Os cristais de clinopiroxênio são euédricos ou subédricos, com hábito prismático, e distribuídos homogeneamente por toda a rocha; entretanto, são também encontrados acumulados em leitos. Suas propriedades óticas indicam pleocroísmo fraco variando de verde oliva $(Y)$, verde-amarronzado $(Z)$ a verde pálido $(X)$, ângulo de extinção $Z \wedge c=34-57^{\circ}$ ou $X \wedge c=34-57^{\circ}$, e ângulo $2 \mathrm{~V}(+)=70-80^{\circ}$, o que permite classificá-lo como um piroxênio alcalino da série egirina-augita. Esta variação composicional é visivelmente indicada pelo zoneamento nos cristais, em que nas bordas o tom verde é mais intenso (egirina), suavizando gradativamente para o núcleo dos cristais (egirina-augita) (Fig. 7F).

Duas gerações de anfibólio foram identificadas, sendo a primeira caracterizada por uma hornblenda primária com pleocroísmo variável de verde-amarronzado pálido $(\mathrm{Z})$, verde-amarronzado $(\mathrm{X})$ a marrom pálido (Y), com ângulo de extinção $\mathrm{Z} \wedge \mathrm{c}=14^{\circ}$, e que se encontra em equilíbrio com piroxênio sódico, microclina e biotita (Fig. 7A). A segunda geração está associada às 


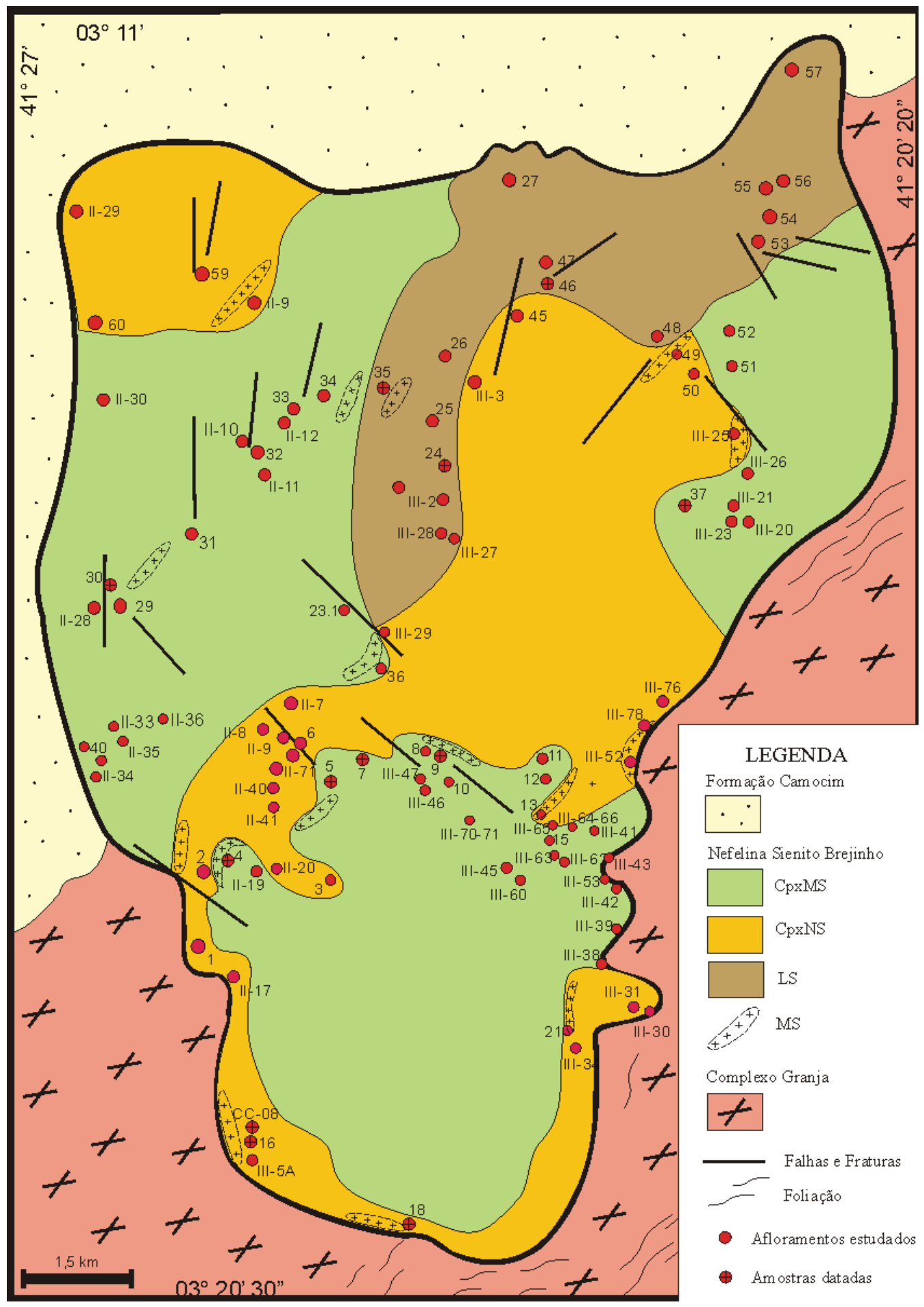

Figura 4 - Mapa geológico simplificado com destaque para as fácies petrográficas do plúton Brejinho.

margens dos cristais de clinopiroxênio na forma de textura coronítica. Neste caso, os anfibólios têm hábito prismático ou fibroso, com pleocroísmo moderado a fraco, de cor azul ou verde, sendo identificados, respectivamente, como riebeckita e tremolita-actinolita, e estão relacionados a reações de hidratação do clinopiroxênio da fase tardia da evolução magmática do plúton (Figs. 7B, C, D).
A biotita tem forte pleocroísmo variando de marrom pálido $(\mathrm{X})$ a marrom-avermelhado $(\mathrm{Y}, \mathrm{Z})$ e, de modo semelhante ao anfibólio, apresenta duas gerações: cristais primários em equilíbrio com os demais minerais magmáticos ou substituindo os cristais de clinopiroxênio nas reações de hidratação.

A titanita é um mineral característico, variando nas proporções desde traço até $1,5 \%$ modal. 


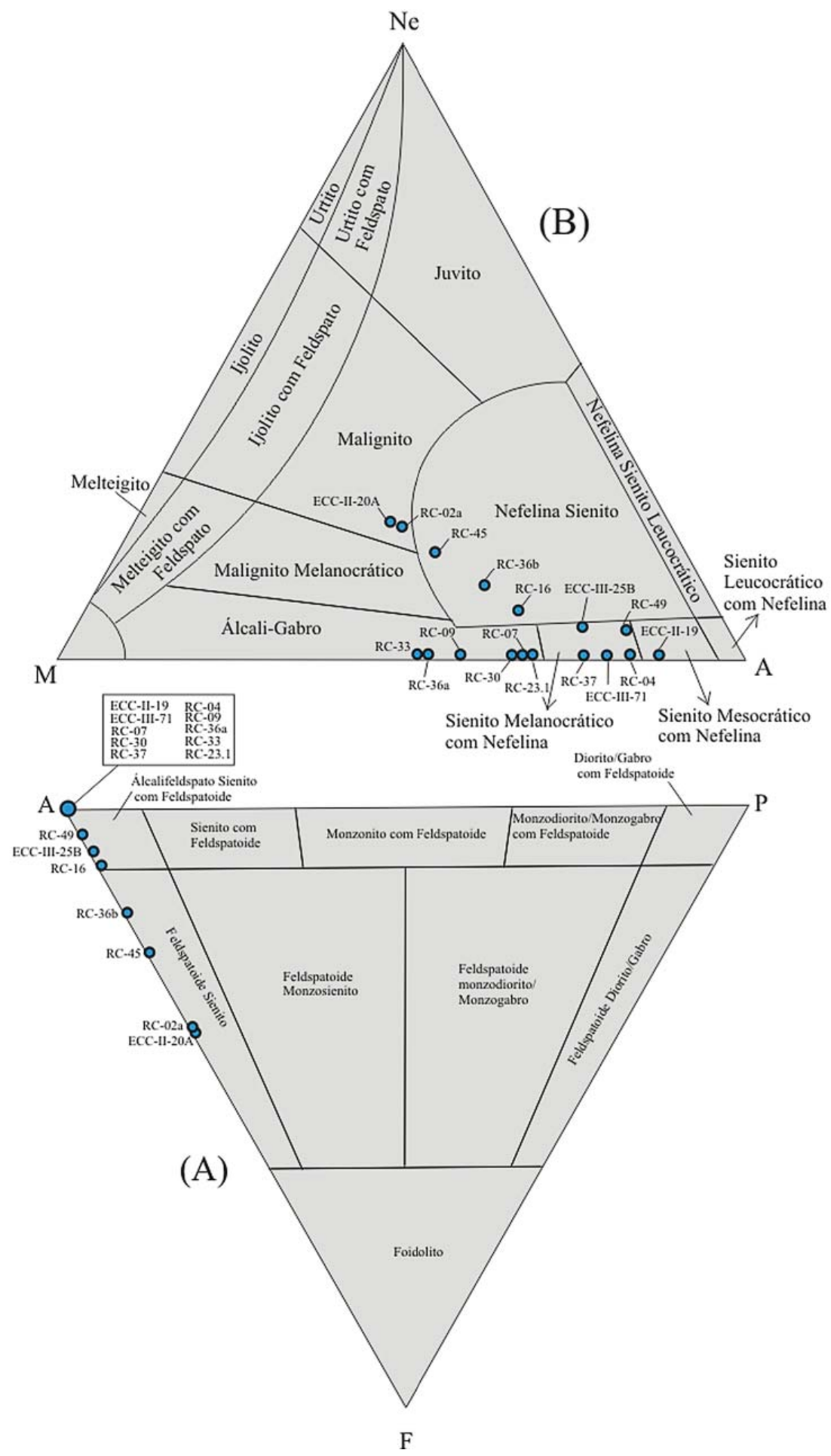

Figura 5 - Classificação das rochas do plúton Brejinho nos diagramas de Streckeisen (1976) (A) e Sarantsina \& Shinkarev (1967 apud Sorensen 1974) (B).

Geralmente forma cristais subédricos ou euédricos, com hábito losangular ou granular. A apatita é o acessório comum, ocorrendo comumente como inclusões nos clinopiroxênios.

Fácies Clinopiroxênio-Nefelina Sienito e Clinopiroxênio-Álcali-feldspato Sienito com Nefelina (CpxNS)
Esta fácies guarda aspectos semelhantes à anterior, sendo, entretanto, diferenciada pela presença de nefelina, ausência de anfibólio e outras particularidades texturais. As suas rochas (31 amostras estudadas) mostram também ampla distribuição, margeando a borda sul do plúton, expandindo-se pela sua porção centro-leste e reaparecendo no extremo noroeste. Juntamente com a 


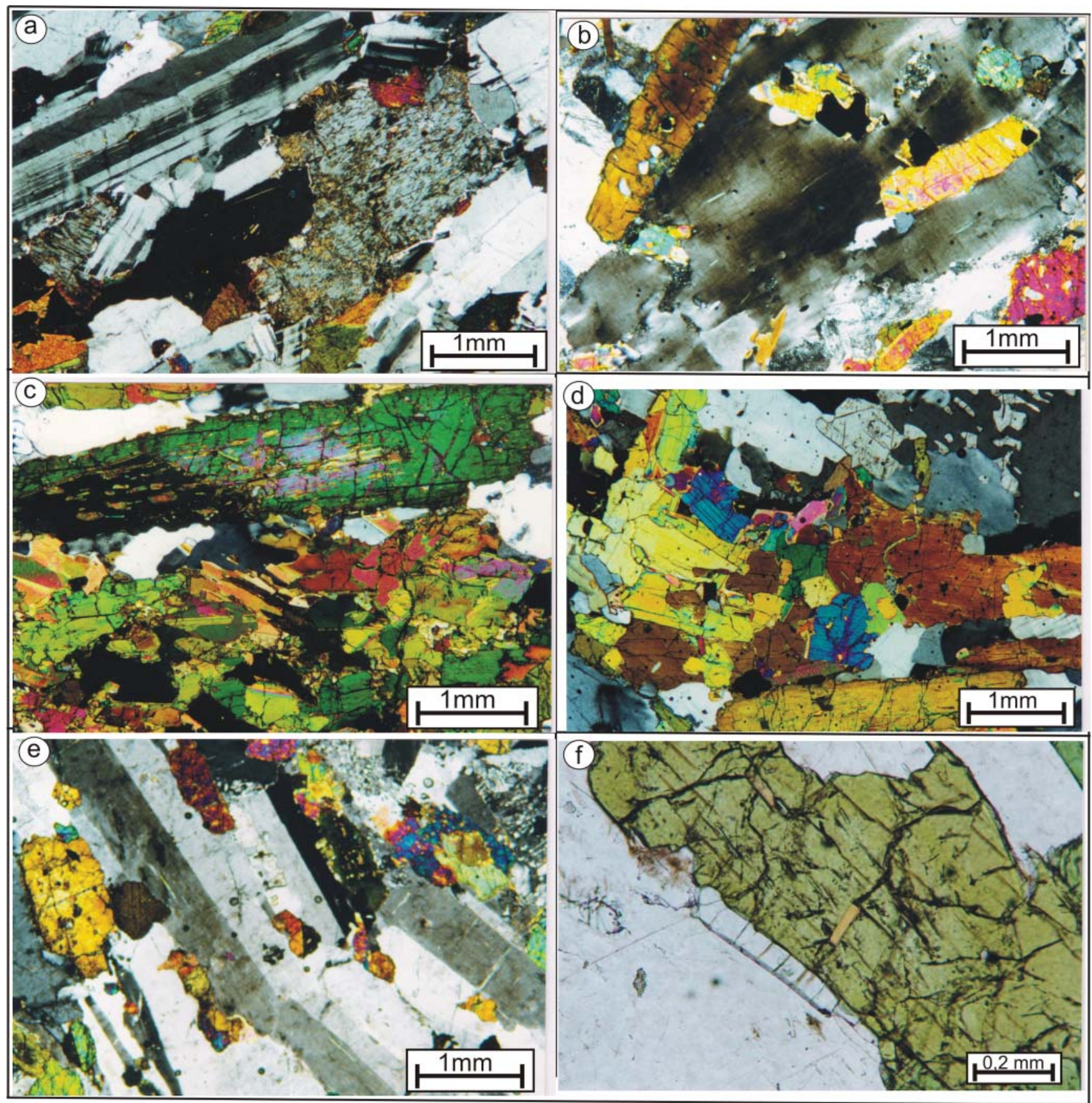

Figura 6 - Aleitamento magmático na escala microscópica: A) orientação preferencial de cristais tabulares de microclina e nefelina; B) idem com microclina e egirina-augita; C e D) piroxenitos com textura cumulada; E) orientação preferencial de microclina e egirina-augita; F) orientação de egirina-augita, apatita e álcali-feldspato.

fácies CpxMS abrange a maior parte da área aflorante do corpo (Fig. 4).

Os clinopiroxênio-nefelina sienitos e os álcali-feldspato sienitos com nefelina são rochas hololeucocráticas a leucocráticas $(\mathrm{M}=7$ a 33), de coloração cinza-esverdeada com manchas marrons, e granulação variável de média a grossa.

Texturalmente, dois aspectos são marcantes nessas rochas: a textura traquitoide e as texturas de intercrescimento (simplectitos nefelina-álcali-feldspato). A primeira, comum à totalidade das amostras, é definida pela orientação subparalela de cristais tabulares de álcali-feldspato e prismáticos de clinopiroxênio (Figs. $6 \mathrm{~A}, \mathrm{~B}, \mathrm{E}, \mathrm{F})$, bem como de outros minerais com iguais características morfológicas.

As texturas de intercrescimento entre nefelina e álcali-feldspato são por vezes muito frequentes. Em geral, ocupam os interstícios dos cristais maiores de clinopiroxênio e de álcali-feldspato, representando fases tardias na evolução dessas rochas (Fig. 8). Ao menos três aspectos morfológicos dos simplectitos foram identificados. Um deles assemelha-se ao intercrescimento gráfico (Figs. 8A, B); outro define arranjos do tipo impressão digital (fingerprint, dactylotypic) (Figs. 
8C, D), que são encontrados em muitos exemplos de rochas alcalinas do mundo, conforme descrição de Bart (1969), Davidson (1970), Smith (1974), Smith \& Brown (1974) e Gittins et al. (1980); e, por último, o intercrescimento nefelina-álcali-feldspato do tipo pertítico (Figs. 8E, F).

A composição mineralógica dos clinopiroxênio-nefelina sienitos é dada essencialmente pela presença de nefelina, álcali-fedspato e clinopiroxênio. Em quantidades menores ocorrem biotita, raramente melanita, e como acessórios titanita, apatita e minerais opacos.

O álcali-feldspato é do tipo microclina, que se apresenta na forma de cristais euédricos, predominantemente com hábito tabular paralelo à face (010). Estão agrupados ordenadamente, orientados subparalelamente e definindo textura cumulada (Figs. 3B e 6A, B, E).
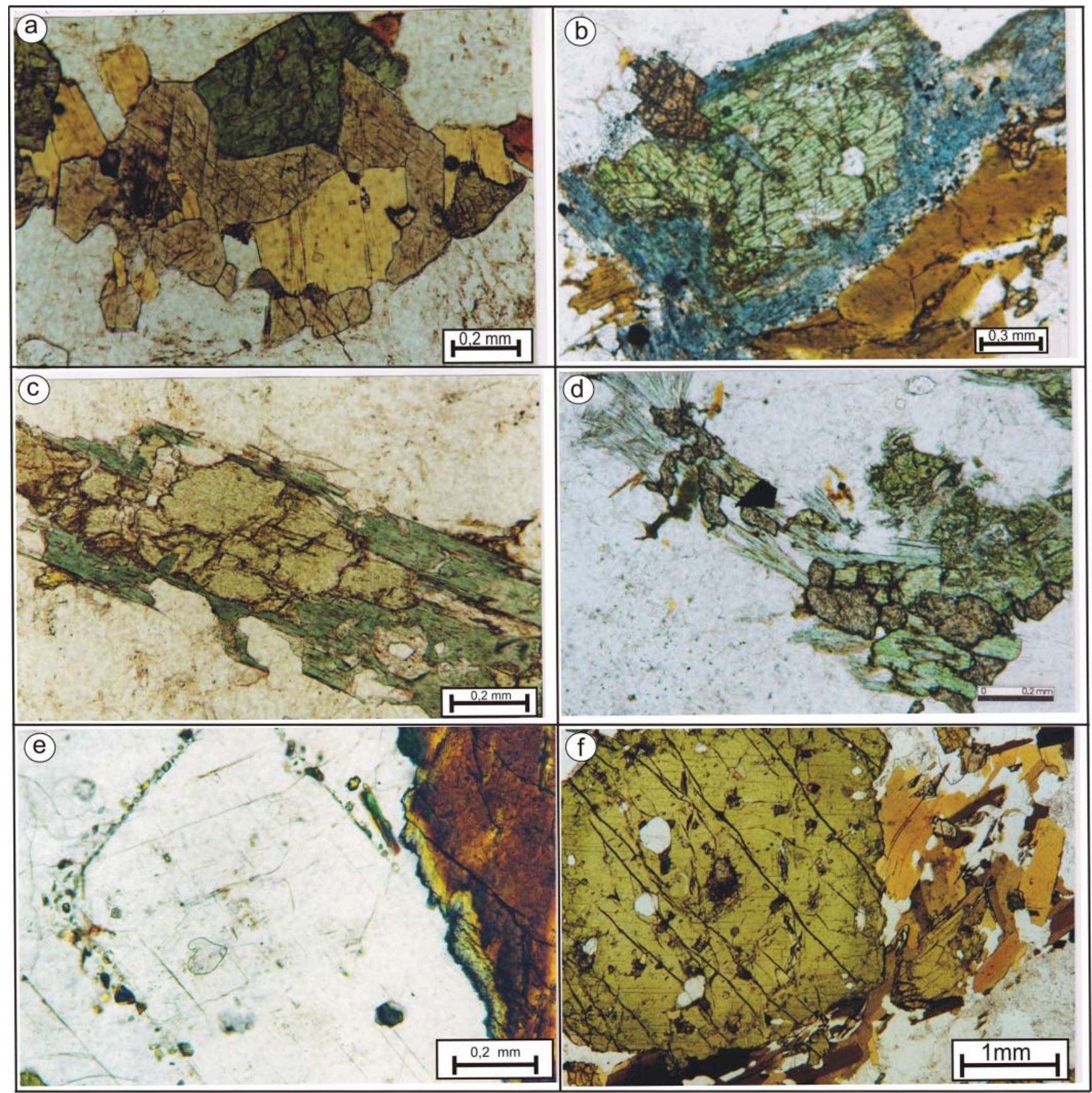

Figura 7 - Aspectos texturais e mineralógicos das rochas do plúton Brejinho: A) hornblenda marrom em equilíbrio com biotita e egirina-augita; $B$ e C) formação de arfvedosonita azul e hornblenda verde, respectivamente, coroando cristais de egirina-augita por reação de hidratação; D) formação de cristais aciculares de tremolita-actinolita e titanita a partir de egirina-augita; E) trilhas de inclusões de egirina delimitando zonas composicionais em cristal de álcali-feldspato; F) cristal de piroxênio sódico mostrando zoneamento composicional (núcleo de egirinaaugita com borda de egirina) e inclusões de apatita e titanita. 
Os maclamentos são em geral do tipo Carlsbad, associado ao Xadrez, e raramente Baveno. Em alguns casos cristais maiores de microclina exibem zoneamento, que é realçado pela presença de trilhas de inclusões de clinopiroxênio, de bordas irregulares (corrosão magmática) e representando fases mais precoces na sequência de cristalização do plúton (Fig. 7E).

Em geral, a nefelina está presente como cristais individuais com formas anédricas a euédricas (Figs. 8E,
F), contendo inclusões de opacos e clinopiroxênio ou, então, intercrescida com álcali-feldspato (Figs. 8A a F), evidenciando as suas duas fases de formação. Normalmente, a nefelina encontra-se alterada para mica branca e argilo-minerais.

O clinopiroxênio de um modo geral segue a estrutura orientada da rocha, porém, ocorre por vezes formando acumulações de cristais (textura cumulada) que podem também reunir biotita, titanita e minerais
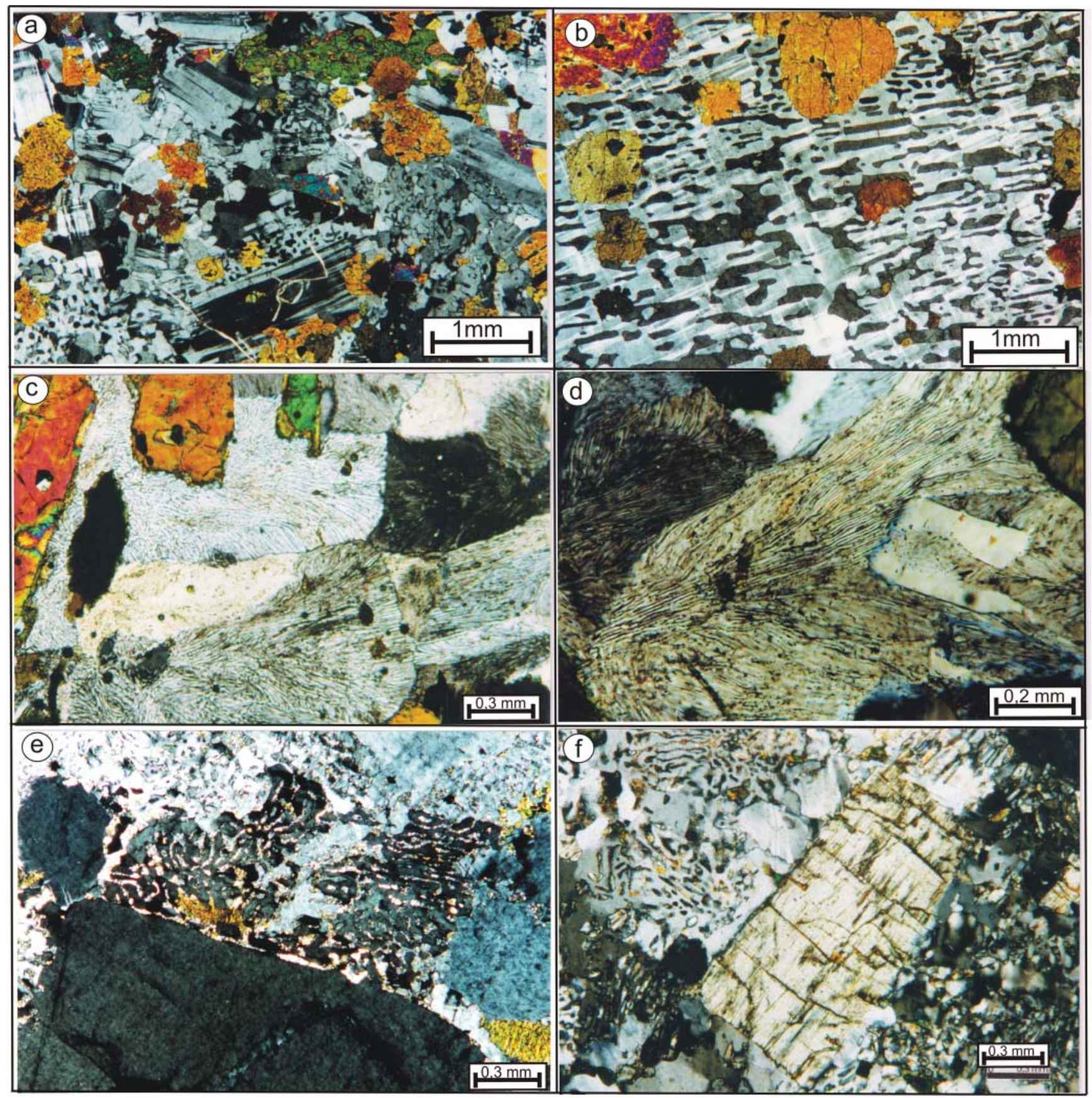

Figura 8 - Texturas de intercrescimento em rochas do plúton Brejinho: A) intercrescimento gráfico microclinanefelina nos interstícios entre cristais de microclina e egirina augita; B) detalhe do intercrescimento gráfico microclina-nefelina; C) intercrescimento álcali-feldspato-nefelina do tipo impressão digital; D) detalhe do intercrescimento do tipo impressão digital; E, F) duas gerações de nefelina (cristais individuais e intercrescimentos vermiformes de nefelina em álcali-feldspato). Todos com nicóis cruzados. 
opacos (Figs. 6C, D). O hábito é prismático, os cristais normalmente euédricos a subédricos exibindo leve pleocroísmo em verde, ângulo de extinção $\mathrm{X} \wedge \mathrm{c}=11^{\circ}, \mathrm{e} 2 \mathrm{~V}$ $(+) \sim 75-80^{\circ}$. Tais características permitem classificá-lo como aegirina-augita. Com base nas feições texturais/ cristalográficas três gerações são reconhecidas. A primeira refere-se a cristais relativamente maiores, euédricos, contendo em geral inclusões de apatita e titanita e mostrando zoneamento composicional (Fig. 7F), onde se distingue um núcleo de coloração verde-amarelada (egirina-augita) e borda de cor verde intenso (egirina). A segunda é caracterizada por cristais menores com pleocroísmo verde intenso, semelhante ao da borda dos cristais maiores, enquanto o terceiro tipo ( $\mathrm{Cpx} 3)$ inclui cristais aciculares de egirina relacionados às fases magmáticas finais (Figs. 9A, B).

A biotita tende a acompanhar a orientação geral da rocha e, frequentemente, está associada ao clinopiroxênio, seja em contato direto ou como inclusões. Ela forma cristais lamelares com pleocroísmo forte de marrom claro a marrom-avermelhado.

A titanita é um mineral comum, com os seus percentuais modais variando de traço até $2 \%$. Ocorre na forma de cristais euédricos ou como inclusões e encontra-se distribuída homogeneamente na rocha. São comuns os hábitos cristalinos losangulares ou prismáticos, orientados segundo a trama geral.

Lamelas e acículas de óxido-hidróxidos de $\mathrm{Fe}$ e Fe-Ti ocorrem ao longo das clivagens e microfraturas dos cristais de clinopiroxênio e microclina, desenhando malhas de intercrescimento formadas provavelmente por processos de exsolução (Figs. 9C, D).

Fácies Leucossienito (LS) Esta fácies acha-se delimitada por uma faixa de aproximadamente $1.500 \mathrm{~m}$ de extensão que se prolonga do centro-norte do corpo em direção nordeste, balizando as fácies CpxMS e CpxNS. De modo mais restrito, tipos microgranulares ou pegmatíticos estão também presentes na forma de veios ou massas irregulares cortando as demais litologias (Fig. 3F). A fácies LS destaca-se das anteriores por sua extrema pobreza em minerais máficos, com índices de cor inferiores a 5 (hololeucocráticas). Entretanto, guardam outras características comuns às fácies descritas anteriormente. São constituídas tanto por nefelina sienitos quanto por álcali-feldspatos sienitos, possuem cor rosada, com algumas variações cinzentas, e granulação grossa a muito grossa.

Do ponto de vista mineralógico, essas rochas são formadas dominantemente por microclina, com nefelina subordinada. Os raros minerais máficos observados

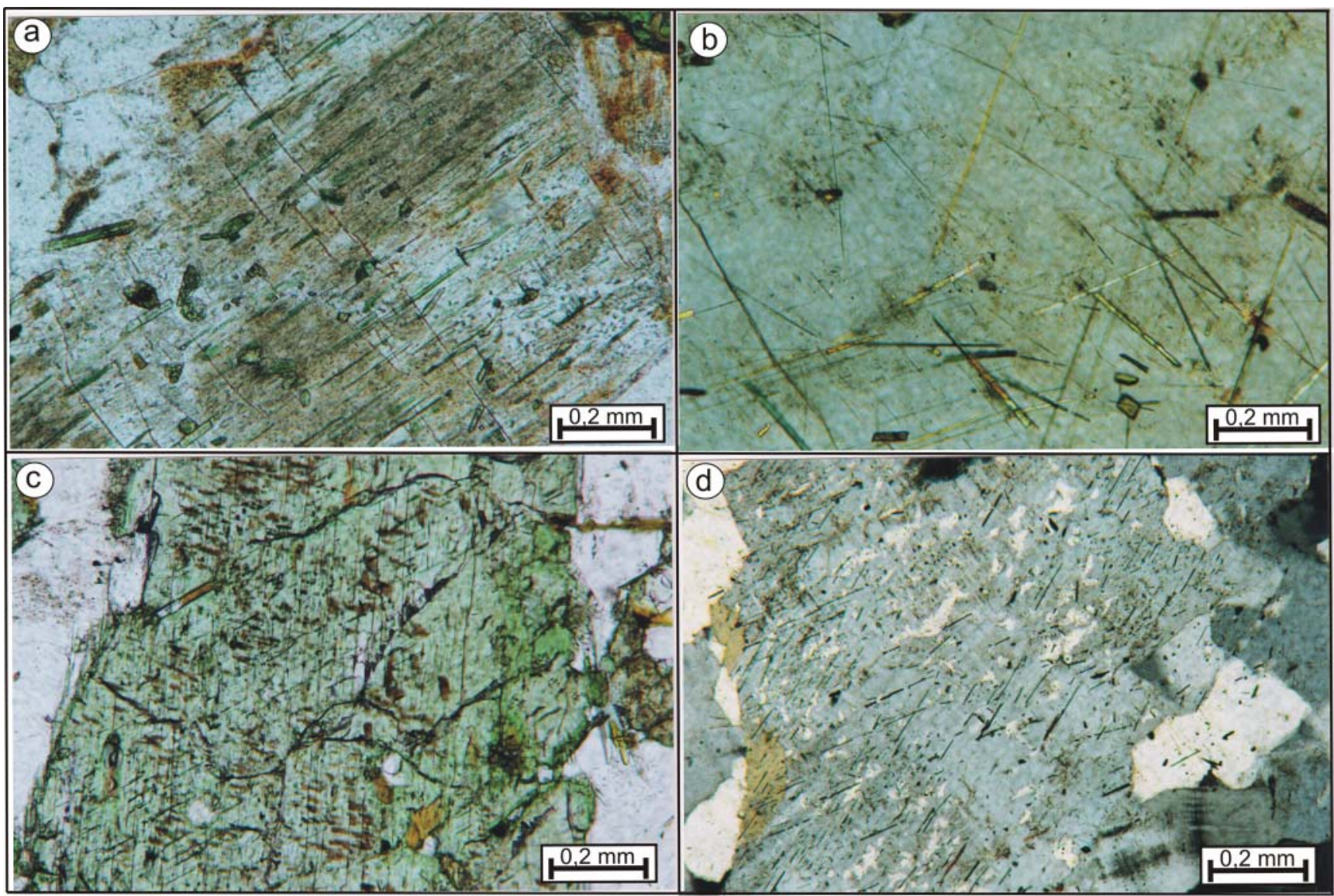

Figura 9 - Feições de inclusão e exsolução nos minerais: A) detalhe das inclusões aciculares de egirina ao longo das clivagens de nefelina; B) cristais aciculares de egirina inclusos em cristal de álcali-feldspato; C e D) lamelas de hematita hospedadas, respectivamente, em egirina-augita e álcali-feldspato pertítico. 
consistem em piroxênios e anfibólios sódicos, biotita, titanita e opacos.

As feições texturais reconhecidas incluem a traquitoide ou granular hipidiomórfica, além de texturas de intercrescimento microclina-nefelina dos tipos gráfico, impressão digital (fingerprint) e vermiforme. Em uma amostra foram identificados pequenos cristais de granada de cor marrom-avermelhada, concentrados em pequenos núcleos associados com biotita verde, apatita e titanita. A sua formação é tardia e a fase caracterizada como melanita (variedade de andradita titanífera presente em rochas alcalinas, segundo Deer et al. 1991).

Fácies Microssienito (MS) Em algumas partes da borda mais externa do plúton ou na proximidade dos limites de fácies foi registrada a presença de microssienitos (Fig. 4), representando produtos do resfriamento rápido típico de margens de resfriamento de corpos intrusivos, e ocorrendo em alguns casos associados com xenólitos (Fig. 3E).

Fácies Mesomelanocrática (MM) Os clinopiroxenitos alcalinos e nefelina sienitos mais ricos em piroxênios $(M>30)$ são de ocorrência rara e restringem-se a pequenas camadas de espessura centimétrica a métrica ou, então, a enclaves englobados pelas rochas das diferentes fácies petrográficas. Apresentam tipicamente textura cumulada, com concentrados de cristais prismáticos de egirina-augita e egirina orientados preferencialmente definindo aleitamento ígneo.

\section{EVOLUÇÃO DA CRISTALIZAÇÃO DO PLÚTON}

BREJINHO A interpretação sobre a história de cristalização desse plúton tem como base as relações de campo entre as várias fácies petrográficas mapeadas, a análise textural e microestrutural das amostras coletadas e a relação mútua das principais fases minerais.

Os registros iniciais da cristalização da fácies CpxMS são definidos pela formação de apatita e titanita, que estão preservadas como inclusões de pequenos cristais euédricos no interior da egirina-augita e microclina (Figs. 7E, F). A cristalização da egirina-augita (Cpx 1) precedeu um pouco à da microclina, como indicado pela presença de pequenas inclusões de cristais de clinopiroxênio na microclina (Fig. 7C). Logo a seguir, as duas fases minerais cristalizaram simultaneamente, conforme se constata pela textura seriada, que indica o crescimento contínuo de ambos, com formas euédricas e subédricas do Cpx 1 e subédricas da microclina. As texturas do tipo cumulada, definida por agregados de cristais de egirina-augita de tamanhos relativamente grandes (Cpx 1), juntamente com a titanita, sugerem períodos de afundamento de cristais mais densos no processo de cristalização fracionada por ação gravitacional (Figs. 6C, D). As acumulações de álcali-feldspatos podem também ser relacionadas com esse processo, mas, neste caso, por ascensão gravitacional (Fig. 6E). Entretanto, os estudos realizados não foram suficientes para conclusões definitivas.
Como discutido por Sorensen (1974), rochas alcalinas como piroxênio sienitos e foiaítos, que apresentam estruturas acamadadas, podem ser interpretadas de duas formas, uma delas como produto de cristalização in situ, seguida da acumulação de cristais nas paredes da câmara magmática; a outra, por cristalização na forma de uma suspensão de placas de feldspato no líquido magmático, quando ambos tiverem densidades aproximadamente iguais. Sorensen (1974) comenta ainda que, pelo fato das rochas peralcalinas apresentarem um intervalo de tempo de cristalização muito longo, são favorecidas as reações tardimagmáticas bem como a acumulação de cristais, em expressivo volume de magma. Essas observações são importantes, pois feições texturais/estruturais e mineralógicas existentes no plúton Brejinho permitem confirmar a ação desses processos no plúton Brejinho.

$\mathrm{O}$ enriquecimento composicional em sódio no magma residual, no estágio intermediário ou mais tardio da história de cristalização do magma, possibilitou a formação da egirina (Cpx 2) nas zonas externas dos cristais de egirina-augita (Cpx1) (Fig. 7F), ou a cristalização desse mineral (Cpx 2) se dando na forma de grãos individuais de tamanhos menores, com o arrefecimento da temperatura no sistema magmático.

$\mathrm{Na}$ sequência do resfriamento do magma, a cristalização teve progresso com a formação de biotita/ flogopita, seguida da de arfvedsonita (Anf 1), caracterizando, desse modo, uma fase de hidratação parcial do magma. Em alguns casos, a biotita ocorre também como inclusões no próprio anfibólio, o que revela alternâncias na cristalização desses dois minerais ou simultaneidade parcial na cristalização. Assim, a sua associação e relações texturais indicam a ação da fase fluida com predominância de $\mathrm{H}_{2} \mathrm{O}$ no magma residual e enriquecimento em $\mathrm{Fe}$ e $\mathrm{Na}$.

Outro estágio mais evoluído da cristalização está associado com a geração de uma segunda espécie de anfibólio sódico (Anf 2), que acompanha os momentos finais da cristalização do Cpx 2 (Figs. 7B, C), com a atuação da fase fluida prosseguindo até o estágio tardimagmático. Neste caso, trata-se de riebeckita com pleocroísmo em azul, que ocorre circundando cristais de egirina. Logo após, formou-se ainda hornblenda marrom, presente como cristais individuais em equilíbrio com egirina, biotita e álcali-feldspato (Fig. 7A). Segundo Deer et al. (1991), a riebeckita é formada no estágio subsolidus, por meio da ação de fluidos oxidantes; já a arfvedsonita, por outro lado, está relacionada ao estágio magmático. Isto pode explicar a existência de cristais euédricos de arfvedsonita, com faces bem definidas, enquanto que a riebeckita se apresenta principalmente como fase de substituição do clinopiroxênio ou, raramente, como cristais individuais.

Ainda no estágio tardimagmático pode-se incluir a formação de albita, ocorrendo como agregados poligonais nos interstícios da microclina e também em feições de coroas.

O estágio pós-magmático é marcado pela presença de lamelas de exsolução de óxido-hidróxidos de Fe 
e Fe-Ti identificadas nos cristais de clinopiroxênio e de microclina (Figs. 9C, D). Elas se dispõem no seu interior como uma malha de cristais aciculares e lamelares alojados nas clivagens e microfraturas desses minerais. Ainda neste estágio houve a formação de um terceiro tipo de anfibólio (Anf 3), representado por tremolita-actinolita, que se cristalizou sob a forma de pequenos feixes de cristais aciculares e fibrosos substituindo parcialmente os cristais de clinopiroxênio (Fig. 7D), com a sua formação provavelmente ligada a processos hidrotermais.

Outras particularidades sobre a sequência de cristalização são discutidas a seguir. Os fenocristais de álcali-feldspato (cristais precoces) apresentam algumas características do ortoclásio, enquanto que na maioria das rochas o tipo comum é a microclina pertítica. Isto pode sugerir que a cristalização inicial do feldspato se deu em condições hipersolvus, com a formação de um único feldspato sódico-potássico (ortoclásio). Com a evolução da cristalização, o sistema magmático passou à condição subsolvus e processos de exsolução levaram a sua transformação em microclina pertítica.

Os cristais menores de microclina contêm grande número de inclusões aciculares de egirina, caracterizando um terceiro tipo de clinopiroxênio ( $\mathrm{Cpx} 3)$ (Fig. 9B), situação não observada nos cristais maiores de microclina. Isto sugere que o clinopiroxênio teve um período mais longo de cristalização, assim como o álcali-feldspato, o que é corroborado pelas considerações de Sorensen (1974) em que a cristalização de rochas peralcalinas desenvolve-se em intervalo muito longo, em comparação com outros magmas. No caso estudado, a cristalização do clinopiroxênio não deve ter sido contínua, com dois estágios de formação claramente definidos. Além disso, as inclusões aciculares de egirina (Cpx 3) estão associadas com inclusões fluidas na microclina, confirmando, assim, a sua formação nos estágios mais evoluídos da cristalização magmática.

A apatita, embora de cristalização precoce, deve ter tido também um período mais amplo de formação, como sugerido pelas suas relações de contemporaneidade com a egirina-augita e microclina (Fig. 6F).

Deve-se ressaltar, ainda, que a titanita mostra mais de uma fase de crescimento, sendo identificada tanto como cristais precoces (inclusões nos piroxênios e feldspatos), como nas fases mais tardias, onde apresenta caráter intersticial a exemplo da biotita.

No caso da fácies CpxNS a ordem de cristalização segue, em linhas gerais, a descrita para a fácies CpxMS, sendo a principal diferença a presença sistemática da nefelina, que exibe marcantes texturas de intercrescimento nefelina-álcali-feldspato (Figs. 8A a F).

A cristalização do clinopiroxênio (egirina-augita) teve início com a formação de cristais prismáticos relativamente pequenos e foi seguida pela do álcali-feldspato, com os cristais tabulares maiores de microclina englobando os primeiros. A ação da gravidade teve papel importante nesse momento, propiciando a acumulação do álcali-feldspato, provavelmente por ascensão gravitacional, tanto nas porções laterais quanto no interior do plúton, e levando ao desenvolvimento de pronunciado bandamento magmático e de texturas do tipo cumulática e traquitoide.

A formação da biotita se dá de modo similar ao descrito na fácies anterior, com o mineral restrito aos interstícios dos cristais de clinopiroxênio e álcali-feldspato, indicando cristalização em um estágio tardio.

Os passos seguintes da cristalização fracionada são controlados pelo enriquecimento em sódio e empobrecimento em sílica e componentes cafêmicos no magma residual, favorecendo a formação da nefelina, em que foram reconhecidas duas fases de formação. A primeira é representada por cristais individuais, em geral euédricos a subédricos (Nef 1), cristalizados diretamente do magma; e a segunda (Nef 2) definida pela cristalização simultânea com o álcali-feldspato, definindo texturas simplectíticas (Figs. 8A a F); por vezes, tem-se também a formação de egirina, condicionada ao isolamento do líquido residual nos interstícios, na fase magmática tardia.

Essa situação é melhor compreendida ao se analisar a cristalização no sistema ternário $\mathrm{SiO}_{2}$-Nefelina $\left(\mathrm{NaAlSiO}_{4}\right)$-Kalsilita $\left(\mathrm{KAlSiO}_{4}\right)$, considerando a situação da parte deficiente em sílica, nas condições de cristalização em torno do ponto minimum (Hydmann 1972, Philpotts 1990). Nessas condições, com o arrefecimento da temperatura, tem-se a formação de nefelina num primeiro momento, porém, com a mudança composicional do líquido residual, a cristalização dirige-se à linha cotética, onde se dá o aparecimento simultâneo de nefelina e álcali-feldspato, até o consumo total do líquido residual.

Tanto a microclina quanto a nefelina apresentam inclusões de clinopiroxênio acicular, em quantidades expressivas, sugerindo nucleação múltipla desses cristais até os estágios mais tardios da cristalização do líquido residual. Uma feição que ilustra essa situação é a presença de cristais zonados de microclina, em que nas fronteiras entre as zonas composicionais as trilhas de inclusões de egirina acicular emolduram as zonas de crescimento dos cristais de microclina. A microclina por sua vez, na continuidade do seu crescimento, engloba também os outros cristais de clinopiroxênio.

O estágio tardimagmático é marcado pela simultaneidade da cristalização do álcali-feldspato com a nefelina registrado pelas texturas simplectíticas (Fig. 8). A cristalização se deu a partir de um líquido residual enriquecido em sódio e empobrecido em elementos cafêmicos, que foi aprisionado nos interstícios dos cristais maiores e que se acha relacionado a um estágio avançado da cristalização, a partir do qual todo o líquido foi cristalizado.

Os simplectitos, presentes na forma de diversos tipos (impressão digital, vermiforme, lamelar ou gráfico), marcam, assim, o final do estágio magmático em condições similares às do ponto eutético do sistema ternário acima.

Alterações das várias fases minerais, tais como substituições parciais de nefelina por zeólitas e carbonatos e piroxênio por tremolita-actinolita, são indicativos de transformações no estágio pós-magmático. 
GEOCRONOLOGIA Rb-Sr Neste estudo aplicou-se a metodologia $\mathrm{Rb}-\mathrm{Sr}$ em rocha total visando definir a idade de colocação do plúton. A escolha da metodologia se baseou no fato de a amostragem feita ser muito bem representativa do plúton, das rochas serem cogenéticas e o corpo não mostrar qualquer indício de metamorfismo, deformação ou transformações metassomáticas, satisfazendo, assim, os seus princípios teóricos (Faure 1986, Rollinson 1993). Além disso, essa opção foi também devida ao fato de a datação em cristais de zircão e titanita ter apresentado problemas analíticos.

Dezoito amostras de nefelina sienitos e sienitos foram selecionadas para o estudo geocronológico, com base nos dados de campo e nos estudos petrográficos. De posse das dosagens de $\mathrm{Rb}$ e $\mathrm{Sr}$, seis delas foram excluídas em função da distribuição linear das razões $\mathrm{Rb} /$ $\mathrm{Sr}$, sendo as doze restantes analisadas no espectrômetro de massa VG ISOMASS 54E do Laboratório de Geologia Isotópica (Pará-Iso) do Instituto de Geociências da Universidade Federal do Pará. Os resultados analíticos encontram-se na tabela 1. Os diagramas isocrônicos foram calculados de acordo com o modelo de York (1969) e os dados oferecidos com desvio padrão de $2 \sigma$.

O diagrama isocrônico construído não apresentou alinhamento ideal, resultando em um alto valor de MSWD, 25,68. A análise do diagrama indicou um maior afastamento das amostras RC-09, RC-24, RC-30 e RC46 na isócrona, as quais foram novamente analisadas no espectrômetro, descartando-se qualquer problema analítico. Avaliando a situação geológica dos pontos de coleta e os dados petrográficos verificou-se que as amostras RC-24 e RC-46 correspondem a leucossienitos de um estágio mais evoluído do plúton e com maiores valores da razão $\mathrm{Rb} / \mathrm{Sr}$, enquanto as outras duas (RC-09 e RC-30) referem-se a fases microgranulares (pequenos corpos ou diques) igualmente relacionadas aos estágios mais tardios na evolução magmática do corpo. Excluídas essas quatro amostras do cálculo, o diagrama reconstruído mostrou um bom alinhamento na reta isocrônica e uma idade de $545 \pm 11 \mathrm{Ma}$, com razão inicial de $0,7113 \pm$ 0,0002 e MSWD de 1,32 (Fig. 10), que pode ser considerada representativa da idade de cristalização do plúton.

Considerando as características intrusivas, as relações estratigráficas observadas no campo e a inexistência de deformação ou metamorfismo superposto, esse valor é interpretado como sendo a idade mínima para a cristalização e emplacement do plúton alcalino, o que permite situá-lo no final do Neoproterozoico, e que tem correspondentes magmáticos cronocorrelatos no noroeste da Província Borborema.

Por outro lado, a curva de evolução da razão ${ }^{87} \mathrm{Sr} /{ }^{86} \mathrm{Sr}$ (Fig. 11) apresenta valor elevado $(0,717)$ para as rochas investigadas, sugerindo que o magma gerador do NSB proveio de fonte mantélica com forte contaminação crustal ou de material da crosta continental.

CONTEXTUALIZAÇÃO TECTÔNICA A região noroeste da Província Borborema é marcada por forte fatiamento crustal envolvendo unidades com idades diversas do Paleoproterozoico ao Paleozoico (Abreu et al. 1988, Gaudette et al. 1993, Torquato 1995, Fetter et al. 2000).

A estruturação marcante segue trends NE-SW e dezenas de lineamentos, cujo principal é o Lineamento Sobral-Pedro II, que correspondem a zonas de cisalhamento transcorrentes de variadas dimensões e que foram reativadas em diferentes períodos da evolução geológica da região. Um desses eventos, do final do Neoproterozoico-início do Paleozoico, é caracterizado pela formação de grábens e horsts no domínio crustal chamado Médio Coreaú com a geração do sistema transtrativo Ubajara-Jaibaras (Abreu et al. 1993). Associam-se a esse domínio crustal dois significativos eventos de magmatismo, o primeiro envolvendo derrames de basaltos intermediários, riolitos e traquitos com caráter efusivo e explosivo, representado pela Suíte Parapui (Gorayeb et al. 1988, Oliveira et al. 2001, Nascimento \& Gorayeb 2004), e o segundo compreendendo o emplacement de diversos plútons graníticos de idade entre 590 e $530 \mathrm{Ma}$, reunidos na Suíte Meruoca (Gorayeb et al. 1988, 1993). Os dados geocronológicos desse plutonismo granítico anorogênico indicam idades situadas no final do Neoproterozoico (532 Ma, Granito Mucambo; 537 Ma, Granito do Pajé; 540 Ma, Granito Meruoca; 562 Ma, Diques Aroeiras; 563 Ma, Granito Tucunduba; e 587 Ma, Granodiorito Anil).

Nesse contexto, o plúton Brejinho, de idade 545 Ma, mostra características geológicas e geocronológicas semelhantes às do plutonismo granítico o que permite associá-lo também ao evento de tectônica extensional ligado à formação do Gráben Jaibaras e outros grábens correlatos do oeste da Província Borborema, conforme relatado por Gorayeb et al. (1993). Na própria área de ocorrência do NSB, um marcante lineamento representado pela Zona de Cisalhamento Santa Rosa foi reativado no final do Neoproterozoico durante a tectônica distensiva ali reconhecida, favorecendo o alojamento do magma alcalino que gerou o plúton. Considerando que este se constitui em um exemplo isolado de magmatismo alcalino subsaturado nessa vasta região da Província Borborema, abrem-se novas perspectivas metalogenéticas e correlativas com outras áreas do Gondwana.

Nesse sentido, o Complexo Alcalino-Ultramáfico-Carbonatítico Maicuru (Lemos et al. 1988, Lemos \& Gaspar 2002), situado no norte do estado do Pará, possui características que possibilitam correlacioná-lo com este evento. Ele está alojado no embasamento gnáissico paleoproterozoico, na borda norte da Bacia do Amazonas, ao longo de um sistema de falhas NE-SW e NW-SE, e apresenta idades Rb-Sr de $589 \mathrm{Ma}$ (Costa et al. 1991). Lemos \& Gaspar (2002) interpretam-no como associado ao rifteamento do Cráton Amazônico pela tectônica distensiva do final do proterozoico que evoluiria para a formação da Bacia do Amazonas.

CONSIDERAÇÕES FINAIS Os estudos realizados no Nefelina Sienito Brejinho, incluindo a cartografia geológica, as relações de contato, as análises de estruturas e texturas, a análise petrográfica de detalhe e a geocronologia permitiram um avanço significativo no 
Paulo Sergio de Sousa Gorayeb et al.

Tabela 1 - Resultados analíticos isotópicos de Rb e Sr de rochas do Nefelina Sienito Brejinho.

\begin{tabular}{lcccccc}
\hline Amostras & $\begin{array}{c}\mathrm{Rb} \\
(\mathrm{ppm})\end{array}$ & $\begin{array}{c}\mathrm{Sr} \\
(\mathrm{ppm})\end{array}$ & $\mathrm{Rb}^{87} / \mathrm{Sr}^{86}$ & $\mathrm{sX}$ & $\mathrm{Sr}^{87} / \mathrm{Sr}^{86}$ & $\mathrm{sY}$ \\
\hline RC-04 & 355 & 361 & 2,8562 & 0,05696 & 0,739436 & 0,000079 \\
\hline RC-05A & 387 & 683 & 1,6444 & 0,03507 & 0,729841 & 0,000045 \\
\hline RC-07 & 278 & 1274 & 0,6314 & 0,01289 & 0,722371 & 0,000048 \\
\hline RC-09 & 367 & 1030 & 1,0323 & 0,01883 & 0,723859 & 0,000052 \\
\hline RC-16 & 384 & 1363 & 0,8153 & 0,01689 & 0,723651 & 0,000045 \\
\hline RC-18A & 807 & 1030 & 2,2722 & 0,05925 & 0,735667 & 0,000076 \\
\hline RC-24 & 1099 & 948 & 3,3655 & 0,11803 & 0,747101 & 0,000029 \\
\hline RC-30 & 216 & 1067 & 0,5861 & 0,00900 & 0,723075 & 0,000110 \\
\hline RC-35 & 395 & 554 & 2,0687 & 0,04032 & 0,733293 & 0,000076 \\
\hline RC-37 & 294 & 1065 & 0,7993 & 0,01286 & 0,723342 & 0,000037 \\
\hline RC-46 & 1628 & 156 & 30,9958 & 1,53286 & 0,989661 & 0,000048 \\
\hline CC-08 & 562 & 1216 & 1,3409 & 0,03126 & 0,727778 & 0,000137 \\
\hline
\end{tabular}

conhecimento desse plúton e da sua ambientação tectônica. Trata-se de um corpo plutônico dominantemente de natureza félsica alcalina, subsaturado, intrusivo em gnaisses do Complexo Granja que, pelo estado atual do conhecimento geológico regional, não tem similar no noroeste da Província Borborema.

No que diz respeito ao corpo em si, o detalhamento petrográfico permitiu individualizar três faciologias petrográficas principais (Clinopiroxênio-Nefelina Sienito, Clinopiroxênio-Microclina Sienito e Leucossienito) e duas mais restritas (Microssienito e Mesomelanocrática), caracterizando as múltiplas fases de evolução petrogenética do plúton, que foram governadas por processos de diferenciação magmática com importante ação da gravidade. Feições texturais/estruturais, relações entre as fases minerais, correlações e interpretações tectônicas nas diferentes faciologias possibilitaram compreender a colocação e o estabelecimento

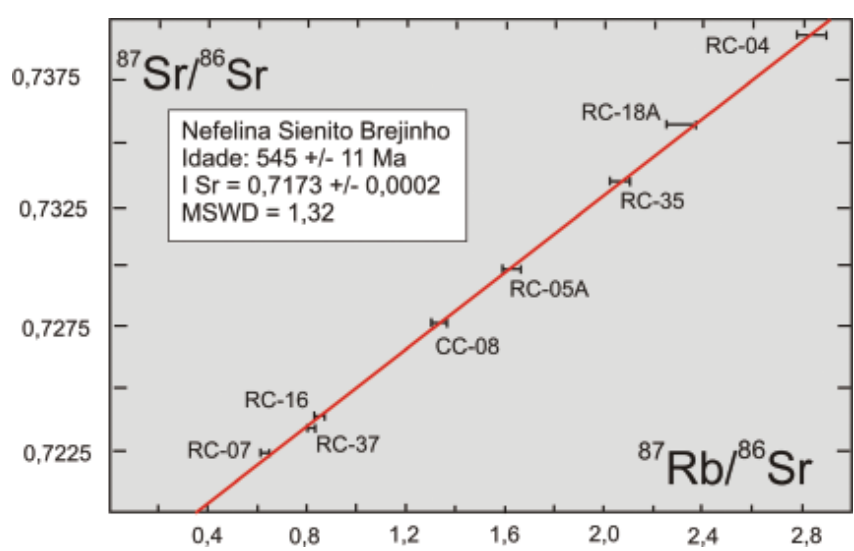

Figura 10 - Diagrama isocrônico Rb-Sr para rochas do plúton Brejinho. do NSB como um raro representante de um episódio de magmatismo alcalino, subsaturado no noroeste da Província Borborema do final do Neoproterozoico, cuja tectônica extensional relacionada sugere vinculação com a pré-abertura da Bacia do Parnaíba.

O episódio de magmatismo alcalino subsaturado identificado neste trabalho, de idade $545 \pm 11 \mathrm{Ma}$, não tem registros na região oeste da Província Borborema, sendo que sua descrição abre novas perspectivas de pesquisa à vista da importância tectônica e metalogenética desse tipo de magmatismo, particularmente em uma região com cartografia geológica razoavelmente bem conhecida.

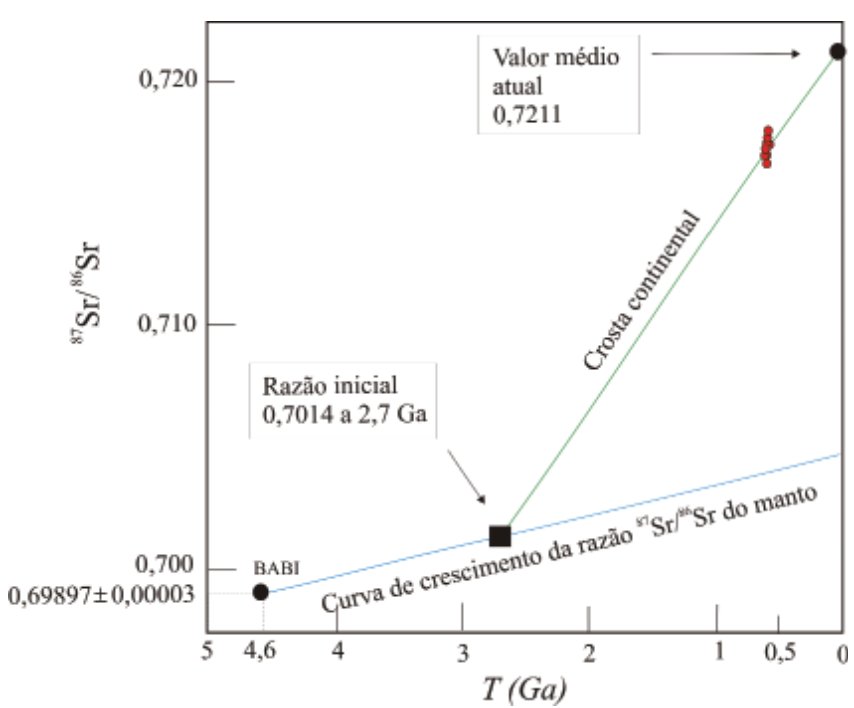

Figura 11- Curva de evolução da razão ${ }^{87} \mathrm{Sr}{ }^{\beta 6} \mathrm{Sr}$ com o tempo na crosta continental e no manto (modificado de Rollinson 1993) com projeção das amostras do plúton Brejinho. 
Quanto à natureza do magma que deu origem às rochas do plúton Brejinho, admite-se uma tendência basáltica alcalina, em razão da existência de enclaves de rochas máficas ou ultramáficas alcalinas que, devido à maior densidade dos magmas, devem ter permanecido nos níveis mais profundos da câmara magmática. Processos de diferenciação magmática comandados pela ação da gravidade foram fundamentais na cristalização do plúton, com menor contribuição de mecanismos como mistura de líquidos magmáticos, responsáveis por algumas das faciologias internas do plúton.

As relações intrusivas do magma alcalino nos gnaisses encaixantes provocaram uma zona relativamente pequena de reação (hornfels), com a associação mineralógica granada+biotita+álcali-feldspato+plagioclásio e a presença de mobilizados de anatexia graníticos sugerindo que o alojamento do corpo ocorreu em condições poucos forçadas, em nível crustal relativamente raso, com temperaturas mínimas de $650^{\circ} \mathrm{C}$.

\section{Referências}

Abreu F.A.M., Gorayeb P.S.S., Gama Jr. T., Hasui Y. 1988. O Cinturão de Cisalhamento Noroeste do Ceará. In: SBGNO, Congresso Latino-Americano de Geologia, 7, Anais, p. 20-33.

Abreu F.A.M., Gorayeb P.S.S., Hasui Y. 1993. Grábens eopaleozóicos do oeste cearense - Considerações sobre as seqüências lito-estratigráficas. In: SBG, Simpósio de Geologia do Nordeste, 15, Atas, p. 29-31.

Almeida F.F.M, Hasui Y., Neves B.B, Fuck R.A. 1977. Províncias estruturais brasileiras. In: SBG, Simpósio de Geologia do Nordeste, 8, Atas, p. 363-391.

Archanjo C.J., Launeau P., Hollanda M.H.B.M. 2009. Scattering of magnetic fabrics in the Cambrian alkaline granite of Meruoca (Ceará state, northeastern Brazil). International Journal of Earth Sciences, 98:1793-1807.

Bart T.F.W. 1969. Feldspars. New York, Wiley Interscience, $216 \mathrm{p}$.

CPRM - Companhia de Pesquisa de Recursos Minerais. 2003. Mapa geológico do estado do Ceará, Fortaleza, mapa geológico, escala 1:500.000.

DNPM - Departamento Nacional de Pesquisa Mineral. 1985. Mapa geológico do Brasil e da área oceânica adjacente. Brasília, mapa geológico, escala 1:2.500.000.

Comin-Chiaramonti P. \& Gomes C.B. (Eds.) 2005. Mesozoic to Cenozoic alkaline magmatism in the Brazilian Platform. São Paulo, Edusp/Fapesp, 752 p.

Costa M.L., Fonseca L.R., Angélica R.S., Lemos R.V.P., Lemos R.L.1991. Geochemical exploration of the Maicuru alkaline-ultramafic-carbonatite complex, northern Brazil. Journal of Geochemical Exploration, 40:193-204.

Costa M.J., França J.B., Lins C.A.C., Bacchiegga I.F., Habekost C.R., Cruz W.B. 1979. Geologia da Bacia de Jaibaras, Ceará, Piauí e Maranhão - Projeto Jaibaras. Brasília, MME/DNPM. 106 p.

Davidson, A. 1970. Nepheline-K-feldspars intergrowth from Kamimak Lake, Northwest Territories. Canadian Mineralogist, 10:191-206.

Deer W.A., Howie R.A., Zussman J. 1991. An introduction to the rock forming minerals. Hong Kong, Longman, 528 p.

Faure G. 1986. Principles of isotope geology. New York, John Willey \& Sons, $589 \mathrm{p}$.

Fetter A.H. 1999. U/Pb and Sm/Nd geochronological and geologic history of Ceará State, NW Borborema
Province, NE Brazil: Implications for the assembly of Gondwana. PhD Thesis, University of North Carolina, Chapel Hill, 146 p.

Fetter A.H., Van Schmus W.R., Santos T.J.S., Nogueira Neto J.A., Arthaud M.H. 2000. U-Pb and $\mathrm{Sm}-\mathrm{Nd}$ geochronological constraints on the crustal evolution and basement architecture of Ceará state, NW Borborema province, NE Brazil: implications for the existence of the paleoproterozoic supercontinente "Atlantica". Revista Brasileira de Geociências, 30:102-106.

Gaudette H.E., Abreu F.A.M., Lafon J.M., Gorayeb P.S.S. 1993. Evolução transamazônica do Cinturão de Cisalhamento Noroeste do Ceará: novas evidências geocronológicas. In: SBG, Simpósio de Geologia do Nordeste, 15, Anais, p. 317-319.

Gittins J., Fawcett J.J., Brooks C.K., Rucklidge J.C. 1980. Intergrowths of nepheline-K-feldspar and kalsilite-Kfeldspar: a re-examination of pseudo-leucite problem. Contributions to Mineralogy and Petrology, 73:119-126.

Gorayeb P.S.S. \& Abreu F.A.M. 1997. O Nefelina Sienito Brejinho, nova ocorrência de intrusão alcalina PréCambriana no oeste da Província Borborema. In: SBG, Simpósio de Geologia do Nordeste, 16, Anais, p. 276-279.

Gorayeb P.S.S. \& Lafon J.M. 1995. Geocronologia Rb-Sr do Granodiorito Anil-CE. In: SBG, Simpósio de Geologia do Nordeste, 15, Anais, p. 274-275.

Gorayeb P.S.S. \& Monteiro E.C. 1996. Os albita granitos da região de Santa Quitéria-Ceará. In: SBG, Congresso Brasileiro de Geologia, 39, Anais, p. 423-425.

Gorayeb P.S.S., Abreu F.A.M., Correa J.A.M., Moura C.A.V. 1988. Relações estratigráficas entre o Granito Meruoca e a Sequência Ubajara-Jaibaras. In: SBG, Congresso Brasileiro de Geologia, 35, Anais, p. 2678-2688.

Gorayeb P.S.S., Abreu F.A.M., Hasui Y. 1993. A tectônica distensiva e a geração de granitos eopaleozóicos no noroeste do Ceará. In: SBG, Simpósio de Geologia do Nordeste, 15, Atas, p. 254-257.

Gorayeb P.S.S., Abreu F.A.M., Moura C.A.V. 1995. Geração de corpos graníticos batolíticos sin-transamazônicos na Província Borborema: o exemplo do Granitóide Chaval. In: Simpósio de Geologia do Nordeste, 15, Anais, p. 254-257.

Gorayeb P.S.S., Tavares Jr. S.S., Lafon J.M. 1991. Novos estudos geocronológicos $\mathrm{Rb}-\mathrm{Sr}$ na região de 
Forquilha-Santa Quitéria-CE. In: SBG, Simpósio de Geologia do Nordeste, 14, Anais, p. 260-263.

Hyndman D.W. 1972. Petrology of Igneous and Metamorphic Rocks. New York, McGraw-Hill Book, 533 p.

Lafon J.M., Tavares Jr. S.S., Gorayeb P.S.S. 1992. Caracterização litoquímica e geocronológica dos granitóides da região de Sobral-Santa Quitéria, NW Ceará. In: SBG, Congresso Brasileiro de Geologia, 37, Anais, p. 371-372.

Le Maitre R.W. 2002. Igneous rocks: a classification and glossary of terms. London, Cambridge University Press, $236 \mathrm{p}$.

Lemos R.L. \& Gaspar J.C. 2002. O magmatismo kamafugítico em Maicuru e seu ambiente tectônico. In: SBG, Congresso Brasileiro de Geologia, 41, Anais, p. 539.

Lemos R.L., Fonseca L.R., Martins L.P.B. 1988. Petrografia do complexo alcalino-ultramáfico-carbonatítico de Maicuru-PA. In: SBG-NO, Congresso Brasileiro de Geologia, 35, Anais, p. 1400-1411.

Mackenzie W.S., Donaldson C.H., Guilford C. 1982. Atlas of igneous rocks and their textures. London, Longman Group Limited, 148 p.

Mitchell R.H. 1996. Classification of undersaturated and related alkaline rocks. In: R.H. Mitchell (ed.) Undersaturated alkaline rocks: mineralogy, petrogenesis, and economic potential. Winnipeg, Mineralogical Association of Canada - Short Course Series 24, p. 1-21.

Mitchell R.H. \& Platt R.G. 1982. Mineralogy and petrology of nepheline syenites from the Coldwell Complex, Ontario, Canada. Journal of Petrology, 23:186-214.

Morbidelli L., Gomes C.B., Beccaluva L., Brotzu P., Conte A.M., Ruberti E., Traversa G. 1995. Mineralogical, petrological and geochemical aspects of alkaline and alkali-carbonatite association from Brazil. Earth Science Reviews, 39:135-169.

Nascimento R.S. \& Gorayeb P.S.S. 2004. Basaltos da Suíte Parapuí, Gráben Jaibaras, noroeste do Ceará: caracterização, petrografia, geoquímica e química mineral. Revista Brasileira de Geociências, 34:459-468.

Oliveira C.O., Martins G., Branco R.M.G.C., Castro D.L. 2001. Um modelo alternativo para a formação da Bacia do Jaibaras: implicações para a evolução final da cadeia Brasiliana/Pan-Africana no noroeste da Província Borborema. Revista de Geologia, 14:11-21.

Philpotts A.R. 1990. Principles of igneous and metamorphic petrology. New Jersey, Prentice Hall, 498 p.

Platt R.G. 1996. Nepheline syenite complexes-an overview. In: R.H. Mitchell (ed.) Undersaturated alkaline rocks: mineralogy, petrogenesis, and economic potential.
Winnipeg, Mineralogical Association of Canada - Short Course Series 24, p. 63-99.

Platt R.G. \& Mitchell R.H. 1982. Rb-Sr geochronology of the Coldwell complex, northwestern Ontario, Canadá. Canadian Journal of Earth Sciences, 19:1796-1801.

Rollinson H. 1993. Using geochemical data: evolution, presentation, interpretation. New York, Longman Group Ltd., 352 p.

Rosa M.L.S., Conceição H., Macambira M.J.B., Galarza M.A., Cunha M.P., Menezes, Marinho M.M., Cruz Filho B.E., Rios D.C. 2007. Neoproterozoic anorogenic magmatism in the Southern Bahia Alkaline Province of $\mathrm{NE}$ Brazil: $\mathrm{U}-\mathrm{Pb}$ and $\mathrm{Pb}-\mathrm{Pb}$ ages of the blue sodalite syenites. Lithos, 97:88-97.

Sarantsina G.M. \& Shinkarev N.F. 1967. Petrography of magmatic andmetamorphic rocks. Linengrad, Nedra, $180 \mathrm{p}$.

Sial A.N. 1987. Granitic rocks of Northeast Brazil. In: International Symposium on Granites and Associated Mineralizations. Extended Abstracts, p. 61-69.

Smith J.V. 1974. Feldspars minerals. Berlin, SpringerVerlag, 690 p.

Smith J.V. \& Brown W.L. 1974. Feldspars minerals. Crystal, chemical and microtextural properties. Berlin, SpringerVerlag, 690 p.

Sorensen H. 1974. The alkaline rocks. New York, John Willey \& Sons, $622 \mathrm{p}$.

Spry A. 1969. Metamorphic textures. London, Pergamon Press, $320 \mathrm{p}$.

Streckeisen H.L. 1976. To each plutonic rocks its proper name. Earth Science Reviews, 12:1-33.

Tavares Jr. S.S., Lafon J.M., Gorayeb P.S.S. 1991. O Granito Serra da Barriga: características petrológicas, geoquímicas e geocronologia Rb-Sr. In: SBG, Simpósio de Geologia do Nordeste, 15, Atas, p. 178-181.

Torquato J.R. 1995. A geologia do noroeste do Ceará: uma visão histórica. Revista de Geologia, 8:5-183.

Ulbrich H.H.G.J. \& Gomes C.B. 1981. Alkaline rocks from continental Brazil. Earth Science Reviews, 17:135-154.

York D. 1969. Least-squares fitting of a straight line with correlated errors. Earth Planetary Science Letters, 5:320-324.

Woolley A.R. 1987. Alkaline rocks and carbonatites of the world - Part 1: North and South America. London, British Museum (Natural History), 216 p.

Manuscrito ID 17630

Submetido em 16 de junho de 2010 Aceito em 13 de outubro de 2011 